\title{
Analiza stanu odżywienia pacjentów poddawanych dializie otrzewnowej*
}

\section{Nutritional status of patients undergoing peritoneal dialysis}

\author{
Joanna Bober', Olech Mazur², Edyta Gołembiewska³, Anna Bogacka, Karina Sznabel', \\ Dobrosława Stańkowska-Walczak , Joanna Kabat-Koperska³ ${ }^{3}$ Ewa Stachowska ${ }^{5}$
}

${ }^{1}$ Zakład Chemii Medycznej Pomorskiego Uniwersytetu Medycznego w Szczecinie

al. Powstańców Wlkp. 72, 70-111 Szczecin

Kierownik: prof. dr hab. n. med. Joanna Bober

${ }^{2}$ Stacja Dializ Szpitala Wojewódzkiego w Koszalinie im. Mikołaja Kopernika

ul. T. Chałubińskiego 7, 75-581 Koszalin

Kierownik: dr n. med. Olech Mazur

${ }^{3}$ Klinika Nefrologii, Transplantologii i Chorób Wewnętrznych Pomorskiego Uniwersytetu Medycznego w Szczecinie

al. Powstańców Wlkp. 72, 70-111 Szczecin

Kierownik: prof. dr hab. n. med. Kazimierz Ciechanowski

${ }^{4}$ Zakład Podstaw Żywienia Człowieka Zachodniopomorskiego Uniwersytetu Technologicznego w Szczecinie

ul. Papieża Pawła VI 3, 71-459 Szczecin

Kierownik: prof. dr hab. Elżbieta Kucharska

5 Zakład Biochemii i Żywienia Człowieka Pomorskiego Uniwersytetu Medycznego w Szczecinie

ul. Broniewskiego 24, 71-460 Szczecin

Kierownik: prof. dr hab. n. med. Ewa Stachowska

\section{SUMMARY}

Introduction: The main causes of death in patients undergoing dialysis are cardiovascular diseases. Their presence is related to the nutritional status of patients treated with peritoneal dialysis, and has a predicted value in this kind of patient. Long-term therapy entails unfavourable changes, from which a clinically significant complication is protein-energy malnutrition and intensification of inflammatory processes.

The aim of the study was to assess the nutritional status of patients with chronic kidney disease treated with peritoneal dialysis based on anthropometric, biochemical parameters analysis, a survey, as well as the determination of changes in measured parameters occurring over time.

Material and methods: The study involved 40 people undergoing peritoneal dialysis (PD) and 30 healthy people. For dialyzed patients testing material was collected twice, every 6 months. Proteins, albumins, prealbumins, C-reactive protein and glucose levels were measured. Anthropometric measurements included body height, body weight, triceps skinfold and subscapular skinfold thickness. Body mass index (BMI) value and exponent of tissue protein source were calculated. The examined patients completed the questionnaire, which included, among other factors, the daily intake of nutrients, and lifestyle information. Results: During the 6 month observation of the PD group a statistically significant increase in the energy value of intake food and amount of calories intake from carbohydrates was found. Analysis of nutritional status dependent on the BMI showed that overweight and obese patients are characterized by higher concentrations of the C-reactive protein and glucose, as well as lower concentrations of prealbumin compared to patients with normal body weight. At the same time, the energy value of food and the amount of protein in the group with BMI $>25$ were smaller than in the other groups. During the 6 month observation a decrease in the concentration of prealbumin and an increase in C-reactive protein in BMI $>25$ group were observed.

Conclusions: The nutritional status of all patients undergoing peritoneal dialysis was abnormal, which was not reflected by BMI. In overweight and obese patients increased changes over time were observed. This suggests the occurrence of protein-energy malnutrition.

Key words: chronic kidney disease, malnutrition, body mass index, prealbumin, C-reactive protein.

\section{STRESZCZENIE}

Wstęp: Główną przyczyną śmierci osób dializowanych są choroby sercowo-naczyniowe. Ich występowanie jest powiązane ze stanem odżywienia pacjentów, który ma wartość predykcyjną u pacjentów poddawanych dializie otrzewnowej. Długotrwała terapia pociąga za sobą niekorzystne zmiany, z których istotnym klinicznie powikłaniem jest niedożywienie białkowo-kaloryczne oraz nasilenie procesów zapalnych.
Celem pracy była ocena stanu odżywienia pacjentów z przewlekłą chorobą nerek leczonych dializą otrzewnową dokonaną na podstawie analizy parametrów antropometrycznych, biochemicznych i ankiet oraz określenie zmian zachodzących w nich z upływem czasu.

Materiał i metody: Badaniu poddano 40 osób poddawanych dializie otrzewnowej (DO) oraz 30 osób zdrowych. U osób chorych materiał do badań pobierany był 2-krotnie, w odstępie

* Praca finansowana z projektu badawczego KBN/NCN 1762/B/P01/2010/39. 
6-miesięcznym. Oznaczono stężenia: białka, albuminy, prealbuminy, białka C-reaktywnego i glukozy. Badania antropometryczne objęły pomiar wzrostu, wagi, grubość fałdu nad mięśniem trójgłowym ramienia i pod łopatką. Obliczono wartość wskaźnika masy ciała (BMI) i wykładnika białkowych zasobów tkankowych. Osoby badane wypełniały ankiety uwzględniające m.in. dobową podaż składników odżywczych oraz styl życia. Wyniki: W trakcie półrocznej obserwacji stwierdzono w grupie DO istotny statystycznie wzrost: wartości kalorycznej przyjmowanych pokarmów oraz ilości energii pobieranej z węglowodanów. Analiza stanu odżywienia w zależności od BMI wykazała że chorzy z nadwagą i otyłością charakteryzują się wyższymi stężeniami białka C-reaktywnego i glukozy oraz mniejszymi prealbuminy w stosunku do chorych z prawidłową masą ciała. Równocześnie zaobserwowano mniejszą niż w pozostałych grupach wartość kaloryczną pokarmów oraz ilość spożywanego białka w grupie z BMI > 25. Podczas półrocznej obserwacji stwierdzono obniżanie się stężenia prealbuminy i wzrost stężenia białka C-reaktywnego w grupie BMI > 25 .

Wnioski: Stan odżywienia wszystkich chorych poddawanych dializie otrzewnowej był nieprawidłowy, czego nie odzwierciedlał BMI. U osób z nadwagą i otyłych stwierdzono narastające w czasie zmiany sugerujące wystąpienie niedożywienia białkowo-kalorycznego.

Słowa kluczowe: przewlekła choroba nerek, niedożywienie, wskaźnik masy ciała, prealbumina, białko C-reaktywne.

\section{WSTĘP}

Jedną z metod leczenia nerkozastępczego stosowanych w przewlekłych chorobach nerek jest ciągła ambulatoryjna dializa otrzewnowa (continuous ambulatory peritoneal dialysis - CAPD). Półprzepuszczalność błony otrzewnowej umożliwia oczyszczanie krwi z kreatyniny, mocznika, potasu i innych substancji gromadzących się w nadmiernej ilości w przebiegu przewlekłej choroby nerek, ale oprócz toksyn przez błonę przechodzą też białka, polipeptydy i aminokwasy niezbędne do prawidłowego funkcjonowania organizmu. $Z$ tego powodu zachodzi konieczność pomiarów stanu odżywienia, które mają wartość predykcyjną u pacjentów poddawanych dializie otrzewnowej. Długotrwała terapia pociąga za sobą niekorzystne zmiany, z których istotnym klinicznie powikłaniem występującym u chorych dializowanych otrzewnowo jest niedożywienie białkowo-kaloryczne. Utrata białek stanowi prawdopodobnie główną przyczynę występowania u dializowanych otrzewnowo obniżonego poziomu albuminy. W przebiegu dializacyjnego zapalenia otrzewnej ilości te mogą znacznie zwiększyć się, głównie w następstwie zwiększenia efektywnego pola powierzchni otrzewnej stanowiącego konsekwencję wzrostu unaczynienia otrzewnej. Czynnikami wpływającymi na stan odżywienia, oprócz obniżonego apetytu powodującego w konsekwencji zmniejszenie podaży składników pokarmowych z dietą, są m.in. uczucie pełności w jamie brzusznej, opóźnione opróżnianie żołądka, absorpcja glukozy z płynu oraz nieprawidłowe usuwanie toksyn mocznicowych.

Ewidentny związek między niedożywieniem a większą śmiertelnością pacjentów dializowanych otrzewnowo nakazuje zwrócenie uwagi na prawidłowe rozpoznanie stanu niedożywienia. Rozpoznanie takiego stanu może być trudne, gdyż nierzadko występuje u pacjentów z nadwagą lub otyłością. Konsekwencją zbyt późno rozpoczętej dietoterapii może być pogorszenie ogólnego stanu pacjentów. Wynika z tego konieczność rutynowego monitorowania stanu odżywienia pacjentów, bez względu na masę ciała, w celu wczesnego wykrycia niedożywienia i jego leczenia.

Najczęściej stosowane biochemiczne markery odżywienia, to białka wisceralne: albumina, prealbumina, białko wiążące retinol i transferyna. Niedożywienie białkowo-kaloryczne występujące u pacjentów leczonych CAPD i przyczynia się do ich zwiększonej zachorowalności oraz śmiertelności. Etiologia niedożywienia jest wieloczynnikowa, ale ważną jej przyczyną jest utrata białek wraz z płynem dializacyjnym. Masa ciała i inne parametry biometryczne nie muszą odpowiadać rzeczywistemu stanowi odżywienia. Stany niedożwienia mogą występować zarówno u osób z niską masą ciała, jak i z otyłością. Zjawisko to jest m.in. konsekwencją wytwarzania substancji aktywnych przez komórki tkanki tłuszczowej, takich jak: leptyna, czynnik martwicy nowotworu, inhibitor aktywatora plazminogenu typu 1, rezystyna oraz adiponektyna [1]. Ponadto adipocyty wykazują ekspresję receptorów leptyny, insulinopodobnego czynnika wzrostu, TNF- $\alpha$, IL-6, TGF- $\beta$. Stan odżywienia pacjentów dializowanych może ulegać dalszemu pogorszeniu po zapaleniu otrzewnej.

Zgodnie z zaleceniami Amerykańskiej Narodowej Fundacji Chorób Nerek (National Kidney Foundation Kidney Disease Outcomes Quality Initiative) [2], stan odżywienia powinien być oceniany na podstawie: subiektywnej oceny ogólnej (subjective global assessment - SGA), wywiadu żywieniowego, badań antropometrycznych i badań biochemicznych. Zakwalifikowanie pacjenta do grupy ryzyka niedożywienia na podstawie skali SGA powinno być stosowane co pół roku. Badania antropometryczne obejmują ocenę masy ciała, indeks masy ciała oraz pomiar grubości fałdu skórnego za pomocą fałdomierza. Obliczona na podstawie wywiadu żywieniowego podaż kalorii (wskazana $35 \mathrm{kcal} / \mathrm{kg} /$ dzień) jest parametrem trudnym do zmierzenia, gdyż konieczna jest ocena przyjmowanej przez pacjenta ilości pożywienia oraz obliczenie ilości wchłoniętej glukozy.

Albumina, parametr najczęściej oznaczany u pacjentów z CAPD, jest silnym predyktorem śmiertelności u pacjentów [3]. Jednak na stężenia albuminy w surowicy ma wpływ kilka czynników. Jej niski poziom w surowicy krwi, obserwowany u pacjentów leczonych CAPD, może odzwierciedlać reakcję ostrej fazy i wynikające z niej straty dializatu oraz albumin w moczu, a tylko w mniejszym zakresie stan złego odżywiania. Inny parametr, prealbumina, jest bardziej wrażliwym wskaźnikiem odżywiania, głównie ze względu na krótszy okres półtrwania tego białka [4]. Konsekwencją zmniejszonego stężenie albumin jest większa zapadalność na infekcje, nasilenie 
miażdżycy oraz chorób układu krążenia, głównych przyczyn przedwczesnej śmierci pacjentów z przewlekłą chorobą nerek leczonych dializami.

Jednym z parametrów różnicującym podział na dwa rodzaje niedożywienia u chorych leczonych dializą otrzewnową jest obecność stanu zapalnego. W pierwszym typie stanu niedożywienia mamy do czynienia z powikłaniami mocznicy, w drugim podwyższone są stężenia cytokin prozapalnych oraz jest wyraźnie nasilony stres oksydacyjny. Niedożywienie typu drugiego jest elementem zespołu MIA (malnutrition-inflammation-atherosclerosis), który związany jest z dużą śmiertelnością [5] Interleukina-6 jest najsilniejszą cytokiną przyczyniającą się do rozwoju zespołu MIA. Działając na hepatocyty, stymuluje produkcję białek ostrej fazy (białko C-reaktywne, fibrynogen, ferrytyna) oraz hamuje syntezę albuminy i transferyny [6]. W przypadku niedożywienia typu pierwszego tradycyjna interwencja żywieniowa daje dobre efekty, natomiast w przypadku typu drugiego konieczne jest zmniejszenie stanu zapalnego. U chorych ze schyłkową przewlekłą chorobą nerek miażdżycy bardzo często towarzyszy niedożywienie, którego wykładnikami są m.in. hipoalbuminemia, hipocholesterolemia oraz spadek wskaźnika masy ciała [7].

Podwyższone stężenie białka C-reaktywnego pociąga za sobą obniżenie stężenia albumin. Jest to efekt reakcji ostrej fazy, w której biorą udział IL-1, IL-6 i TNF- $\alpha$. W konsekwencji stężenie albuminy w surowicy jest wskaźnikiem obu czynników - zapalenia i niedożywienia. Podobnie, jak w całej populacji, u pacjentów leczonych dializą otrzewnową występuje problem otyłości. Prócz ogólnych powodów, dodatkowym czynnikiem zwiększającym ilość tkanki tłuszczowej jest wchłanianie glukozy z płynu dializacyjnego odpowiadające 500-800 kcal dziennie. Ponad połowa chorych leczonych dializą otrzewnową ma otyłość brzuszną. Kontrowersje budzą wyniki powiązań wskaźnika masy ciała pacjentów z przeżyciem. Część badaczy $[8,9]$ uważa, że zwiększona masa ciała jest czynnikiem pozytywnie korelującym z przeżyciem. Inni łączą nadwagę i otyłość ze zwiększonym ryzykiem wystąpienia chorób sercowo-naczyniowych oraz utajonego niedożywienia $[10,11]$.

\section{MATERIA I METODY}

\section{Materiat do badań}

Badaniu poddano 70 osób (40 mężczyzn i 30 kobiet), które podzielono na 2 grupy - pacjentów z przewlekłą chorobą nerek leczonych dializą otrzewnową (DO) oraz grupę kontrolną (GK). Pacjenci poddawani dializie otrzewnowej (22 kobiety i 18 mężczyzn; średnia wieku 53,0 $\pm 16,4$ lat) nie chorowali na czynną chorobę nowotworową i nie mieli aktywnego stanu zapalnego. Byli pod kontrolą Poradni Chorób Nerek i Nadciśnienia Tętniczego Pomorskiego Uniwersytetu Medycznego w Szczecinie (PUM) oraz Stacji Dializ Szpitala Wojewódzkiego w Koszalinie. Grupę kontrolną stanowiło 30 zdrowych osób (12 mężczyzn i 18 kobiet), których średnia wieku (46,4 \5,1 lat) nie różniła się istotnie statystycznie od wieku badanych pacjentów. Badani tej grupy, zgodnie z deklaracjami, nie chorowali na czynną chorobę nowotworową, nie mieli aktywnego stanu zapalnego oraz nie chorowali na choroby nerek.

Pacjenci zostali poddani 2-krotnie, w odstępie 6-miesięcznym, badaniom antropometrycznym, laboratoryjnym oraz ankietowym (DO-1 i DO-2). U osób stanowiących GK badania wykonano jednorazowo. Wszystkie osoby wyraziły pisemną zgodę na udział w badaniach, które uzyskały akceptację Komisji Bioetycznej PUM.

\section{Badania ankietowe}

Pacjenci otrzymywali do wypełnienia ankietę dotyczącą sposobu życia, nawyków żywieniowych oraz tygodniowego jadłospisu. W celu ułatwienia określania racji żywieniowych korzystali z „Albumu fotografii produktów i potraw” [12]. Podobną ankietę wypełniały osoby z grupy kontrolnej. Ocena sposobu żywienia została dokonana na podstawie tygodniowych jadłospisów, które były notowane na bieżąco. Do analizy diet użyto programu „Dietetyk 2".

\section{Pomiary antropometryczne}

Podczas badania lekarskiego pacjenci i osoby zdrowe zostały poddane badaniu antropometrycznemu. Mierzono wzrost, ciężar ciała, grubość fałdu nad mięśniem trójgłowym ramienia (TSF) i pod łopatką, obwód środkowej części ramienia (MAC) oraz wyliczano: wskaźnik masy ciała (body mass index - BMI) $\left\{\right.$ BMI = ciężar $(\mathrm{kg}) /$ wzrost $\left.(\mathrm{m})^{2}\right\}$, a także wykładnik białkowych zasobów tkankowych (mid arm muscle circumference - MAMC) $\{$ MAMC $=$ MAC $-($ TSF $\times 0,3142)\}$, gdzie: MAC - obwód środkowej części ramienia, TSF - grubość fałdu skórnego nad mięśniem trójgłowym. Grubość fałdu nad TSF i pod łopatką mierzona była za pomocą cyrkla antropometrycznego.

\section{Badania laboratoryjne}

Analizę parametrów laboratoryjnych wykonano w surowicy krwi. Do czasu wykonania oznaczeń surowica przechowywana była $\mathrm{w}-80^{\circ} \mathrm{C}$. Poszczególne analizy biochemiczne wykonywano we wszystkich próbkach w tym samym czasie. Stężenie prealbuminy oznaczono w surowicy metodą immunoenzymatyczną (ELISA), przy użyciu zestawów firmy Wuhan EIAab Science Co. Stężenie białka, albuminy, glukozy i białka C-reaktywnego oznaczono typowymi metodami stosowanymi w diagnostyce laboratoryjnej.

\section{Analiza statystyczna zebranych danych}

Obliczenia statystyczne wykonano przy użyciu pakietu Statistica 10.1. Wartości p < 0,05 przyjęto za znamienne statystycznie. W celu rozkładu normalności zmiennych użyto testu W Shapiro-Wilka. Po stwierdzeniu, że rozkład zmiennych nie jest normalny, do dalszej analizy zastosowano testy nieparametryczne. Zależności między badanymi parametrami w dwóch punktach czasowych określano testem kolejności par Wilcoxona. Zależności pomiędzy poszczególnymi grupami badano testem U Manna-Whithneya (test nieparametryczny dla dwóch prób niezależnych). Wyniki przedstawiono jako wartość średnią \pm SD. 


\section{WYNIKI}

Wyniki przedstawiono w tabelach 1-4, a wybrane różnice istotne statystycznie pomiędzy grupami w tabeli 5.

\section{Omówienie wyników badań ankietowych - styl życia i nawyki żywieniowe}

Osoby chore swój stan zdrowia oceniały jako dobry (31,5\%) oraz średni (42,1\%), natomiast jako słaby lub zły odpowiednio 15,8 oraz 5,3\%. Także 5,3\% osób stwierdziło, że ich stan zdrowia jest

TABELA 1. Wybrane parametry antropometryczne w badanych grupach oraz wyniki badań laboratoryjnych

\begin{tabular}{|c|c|c|c|}
\hline $\begin{array}{ll}\text { Parametr } & \text { Grupa }\end{array}$ & DO-1 $(n=40)$ & DO-2 $(n=40)$ & GK $(n=30)$ \\
\hline $\mathrm{BMI}\left(\mathrm{kg} / \mathrm{m}^{2}\right)$ & $26,1 \pm 4,7$ & $26,5 \pm 5,0$ & $25,3 \pm 3,4$ \\
\hline Grubość fałdu skórnego nad mięśniem trójgłowym (mm) & $22,1 \pm 9,2$ & $23,2 \pm 8,5$ & $25,9 \pm 7,5$ \\
\hline Grubość fałdu skórnego pod łopatką (cm) & $21,6 \pm 7,9$ & $22,3 \pm 7,9$ & $23,6 \pm 6,9$ \\
\hline MAMC (cm) & $22,5 \pm 3,1$ & $22,6 \pm 3,5$ & $22,0 \pm 2,4$ \\
\hline Obwód środkowej części ramienia (cm) & $29,5 \pm 3,5$ & $26,5 \pm 5,0$ & $30,2 \pm 2,6$ \\
\hline Albumina surowicy (g/L) & $39 \pm 4$ & $39 \pm 4$ & $41 \pm 3,4$ \\
\hline Białko surowicy (g/L) & $67 \pm 4,5$ & $67,8 \pm 6,2$ & $74 \pm 4,8$ \\
\hline Białko C-reaktywne (mg/L) & $7,7 \pm 9,5$ & $28,4 \pm 48,9$ & $<5$ \\
\hline Prealbumina (mg/dL) & $430,6 \pm 202,4$ & $388,0 \pm 235,6$ & $439,1 \pm 195,1$ \\
\hline Glukoza (mg/dL) & $103,8 \pm 25,7$ & $99,6 \pm 20,8$ & $100,7 \pm 26,0$ \\
\hline
\end{tabular}

DO - pacjenci z przewlekłą chorobą nerek leczeni dializą otrzewnową; GK - grupa kontrolna; BMI - wskaźnik masy ciała; MAMC - wykładnik białkowych zasobów tkankowych

$\dagger-$ zmiany istotne statystycznie między DO-1 a DO-2, p < 0,05;

TABELA 2. Wybrane parametry antropometryczne oraz wyniki badań laboratoryjnych w zależności od wartości wskaźnika masy ciała (BMI)

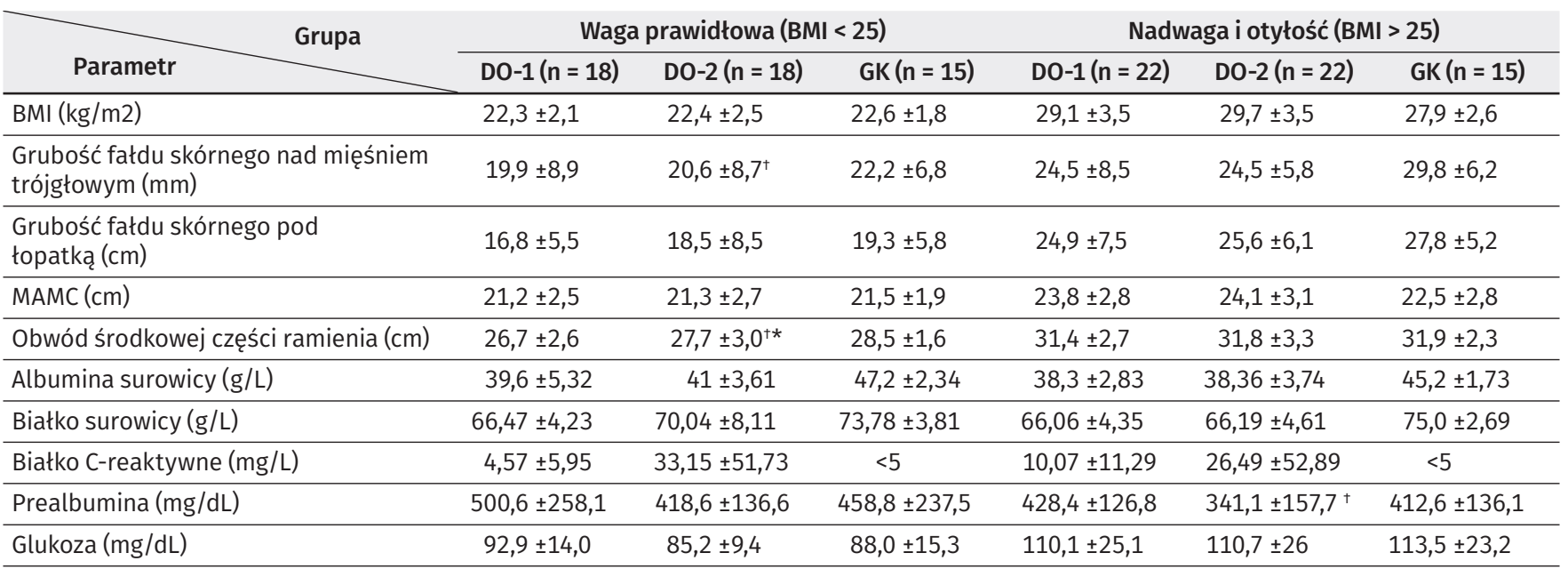

DO - pacjenci z przewlekłą chorobą nerek leczeni dializą otrzewnową; GK - grupa kontrolna; MAMC - wykładnik białkowych zasobów tkankowych

† - zmiany istotne statystycznie między DO-1 a DO-2; p<0,05; różnice istotne statystycznie między DO a GK

* $-\mathrm{p}<0,05$

TABELA 3. Dobowa wartość kaloryczna posiłków, struktura pobierania energii z pożywienia oraz zawartość głównych składników w dziennych racjach pokarmowych chorych dializowanych

\begin{tabular}{|c|c|c|c|c|}
\hline Parametr Grupa & DO-1 $(n=40)$ & DO-2 $(n=40)$ & GK $(n=30)$ & $\begin{array}{c}\text { Wartości } \\
\text { pożądane (28-34) }\end{array}$ \\
\hline Wartość kaloryczna pokarmów (kcal/d) & $1520 \pm 551$ & $1531 \pm 340^{+}$ & $1615 \pm 464$ & 2500 \\
\hline Energia z białek (\%) & $15,5 \pm 2,2$ & $15,3 \pm 2,2$ & $16,7 \pm 2,8$ & 17 \\
\hline Energia z tłuszczu (\%) & $35,2 \pm 5,2$ & $34,8 \pm 5$ & $34,7 \pm 6,3$ & 38 \\
\hline Energia z węglowodanów (\%) & $49,4 \pm 4,8$ & $50 \pm 5,4^{\dagger}$ & $48,7 \pm 7,4$ & 45 \\
\hline Spożycie białka (g/d) & $56,7 \pm 18$ & $56,3 \pm 11,6$ & $63,7 \pm 14,9$ & $75-110$ \\
\hline Spożycie tłuszczów (g/d) & $61,6 \pm 24,4$ & $61,1 \pm 19$ & $66 \pm 25,6$ & 73 \\
\hline Spożycie węglowodanów (g/d) & $201 \pm 77,2$ & $205 \pm 44,3$ & $210 \pm 63,5$ & $300-400$ \\
\hline Błonnik pokarmowy (g/d) & $17,4 \pm 5,2$ & $17,8 \pm 4,4$ & $19,2 \pm 5,8$ & $20-40$ \\
\hline
\end{tabular}

DO - pacjenci z przewlekłą chorobą nerek leczeni dializą otrzewnową; GK - grupa kontrolna

$\dagger$ - różnice istotne statystycznie między DO-1 a DO-2; $p<0,01$ 
TABELA 4. Dobowa wartość kaloryczna posiłków, struktura pobierania energii z pożywienia oraz zawartość głównych składników w dziennych racjach pokarmowych chorych dializowanych w zależności od wartości wskaźnika masy ciała (BMI)

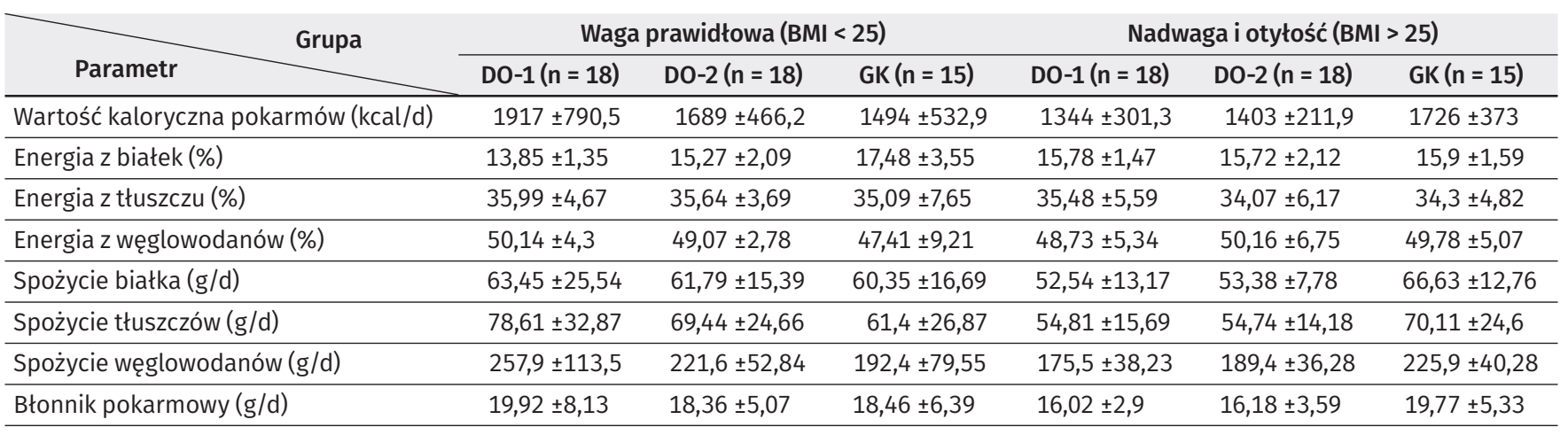

DO - pacjenci z przewlekłą chorobą nerek leczeni dializą otrzewnową; GK - grupa kontrolna

† - różnice istotne statystycznie między D0-1 a DO-2; p < 0,01

TABELA 5. Wartości Z testu U Manna-Whitneya dla różnic istotnych statystycznie w zależności od wskaźnika masy ciała (BMI) między badanymi grupami

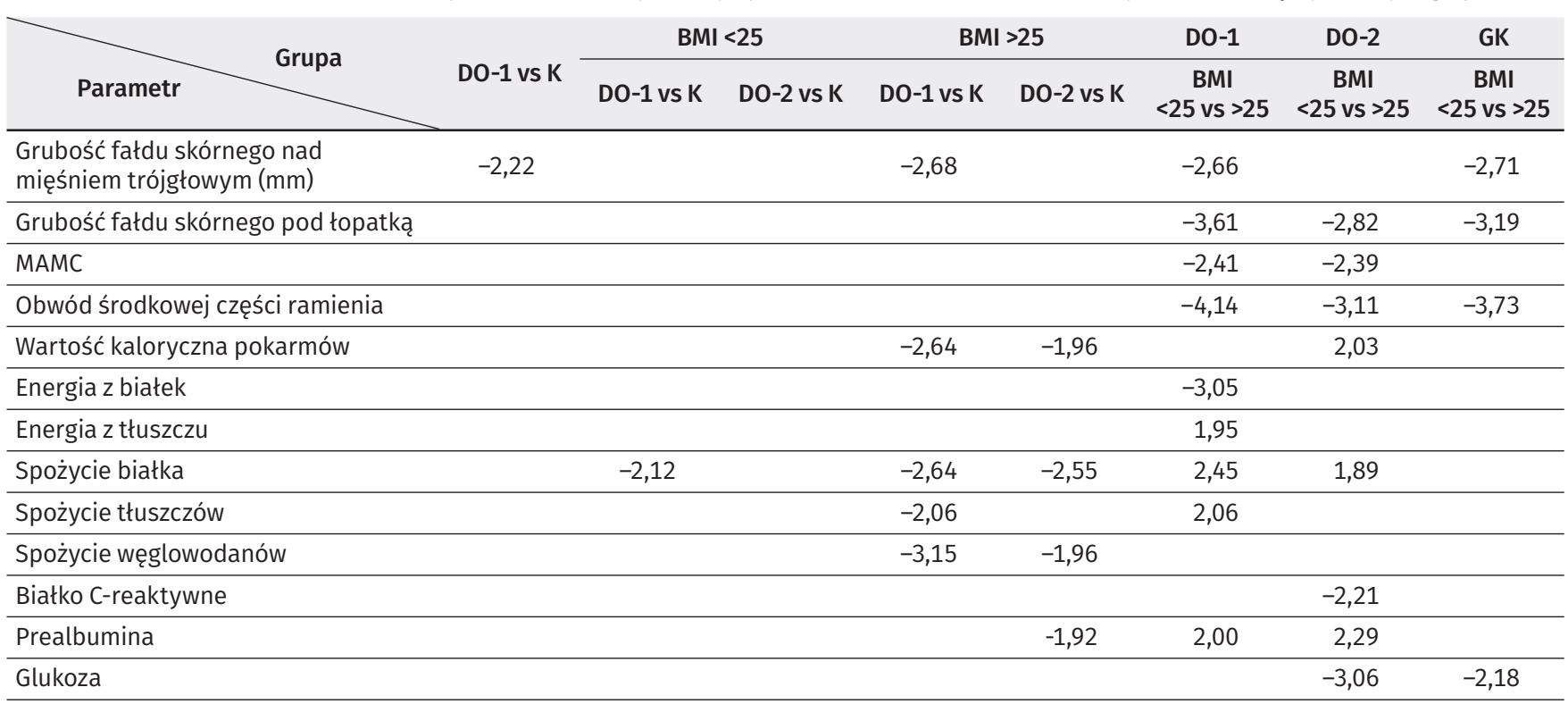

DO - pacjenci z przewlekłą chorobą nerek leczeni dializą otrzewnową; GK - grupa kontrolna; MAMC - wykładnik białkowych zasobów tkankowych

bardzo dobry. Wśród badanych z grupy kontrolnej większość $(80,8 \%)$ oceniała stan zdrowia jako dobry, $15,4 \%$ jako bardzo dobry, a 3,8\% jako średni. Ponad $1 / 3$ osób zdrowych $(36,4 \%)$ nie stosuje specjalnej diety, 30,8\% stosuje dietę niskotłuszczową, a 15,4\% - lekkostrawną. W przeciwieństwie do nich dietę stosuje $87 \%$ chorych $(\mathrm{p}<0,05)$, przy czym przeważa dieta niskosolna $(21,8 \%)$ oraz z ograniczeniem przyjmowania fosforu (17,4\%). Badani z obu grup regularnie spożywali 3-5 posiłków dziennie. Aktywność fizyczna w obu grupach była porównywalna.

\section{Parametry antropometryczne}

Zestawienie parametrów antropometrycznych służących do oceny stanu odżywienia przedstawiono w tabeli 1 . Wyniki BMI interpretowano w oparciu o skalę opracowaną przez Ferro-Luzzi. Prawidłowe wartości BMI miało 41\% kobiet z grupy DO i 56\% kobiet zdrowych. Wśród mężczyzn wartości te wynosiły odpowiednio 33\% i $42 \%$. Nadwagę stwierdzono u $41 \%$ kobiet chorych (33\% zdrowych) oraz u 39\% mężczyzn chorych (42\% zdrowych), a otyłość u 14\% i 11\% kobiet oraz 28\% i 17\% mężczyzn. W czasie półrocznej obserwacji nie stwierdzono istotnych statystycznie zmian w wartościach BMI, różnic między grupami w obrębie tej samej płci oraz w wartościach BMI, TSF, a także grubości fałdu skórnego pod łopatką w zależności od płci w grupach osób chorych i zdrowych. Natomiast wartość MAMC nie zależy od grupy, ale od płci i u kobiet obu grup jest istotnie niższa $(\mathrm{p}<0,001)$ niż u mężczyzn (w tych samych grupach).

Zarówno grupy poddawane dializie, jak i grupę kontrolną podzielono ze względu na wartość BMI na podgrupy o prawidłowej jego wartości (BMI < 25) oraz wysokiej. Ze względu na niską liczebność grup z nadwagą oraz otyłością, w celach dalszej analizy statystycznej połączono w jedną grupę osoby mające BMI > 25. W tabeli 2 przedstawiono parametry antropometryczne w zależności od wartości BMI. Osoby zdrowe, o prawidłowej wartości BMI, miały większy obwód środkowej 
części ramienia $(\mathrm{p}<0,05)$ niż osoby chore. Analogiczną zależność stwierdzono w grupach o BMI > 25. W trakcie półrocznej obserwacji grupy DO stwierdzono wzrost grubości fałdu skórnego nad mięśniem trójgłowym $(\mathrm{p}<0,05)$ oraz obwodu środkowej części ramienia $(\mathrm{p}<0,05)$.

\section{Analiza struktury diet}

Wartość energetyczną, strukturę pobierania energii z pożywienia oraz spożycie wybranych składników pokarmowych w badanych grupach przedstawiono w tabelach 3 i 4, a najważniejsze różnice istotne statystycznie między grupami w tabeli 5. Średnie pobranie energii zarówno w grupie chorych, jak i u osób zdrowych było niższe od ilości zalecanych, a procent realizacji normy wynosił odpowiednio 60,8 (D0-1), 61,2 (DO-2) i 64,6 (GK). Nie stwierdzono różnic istotnych statystycznie między grupami. Wartość procentowa energii pobieranej z głównych składników pokarmowych (białek, tłuszczu, węglowodanów) w niewielkim stopniu odbiega od wartości prawidłowych. Najmniej energii czerpią osoby chore z białek (ok. 90\%); w przeciwieństwie do nich GK osiąga prawie 100\% wartości pożądanej. Różnice między grupami są istotne statystycznie $(\mathrm{p}<0,05)$. W obu grupach najmniej energii czerpane jest z tłuszczów (ok. 91\% wartości pożądanych), a najwięcej z węglowodanów (ok. 110\% wartości pożądanych). Nie stwierdzono różnic istotnych statystycznie między grupami GK i DO, oprócz różnicy w ilości energii czerpanej z białek. W trakcie półrocznej obserwacji zaobserwowano istotny statystycznie wzrost wartości kalorycznej przyjmowanych pokarmów oraz wzrost ilości energii pobieranej z węglowodanów. Zawartość tłuszczów w dziennych racjach żywnościowych była zbliżona w obu grupach i nie odbiegała od wartości zalecanej. Spożycie węglowodanów we wszystkich grupach było niższe niż zalecane. Poniżej zalecanych wartości była także podaż białka, która u osób chorych wynosiła ok. 60\% wartości prawidłowej. W grupach poddawanych dializie zbyt niskie było też spożycie błonnika pokarmowego. Porównanie grup o BMI < 25 nie wykazało różnic w dietach między osobami zdrowymi a dializowanymi, za wyjątkiem zmniejszonej zawartości białka $\mathrm{w}$ diecie osób chorych $(\mathrm{p}<0,03)$. Analizując grupy z BMI > 25, stwierdzono że pacjenci dializowani spożywają posiłki o niższej kaloryczności $(\mathrm{p}<0,01)$ oraz zawierające mniej białka, tłuszczu i węglowodanów niż osoby zdrowe $(\mathrm{p}<0,005)$. Zaobserwowano, że chorzy o BMI > 25 pobierali więcej energii z białek, natomiast mniej z tłuszczu, a także spożywali mniej białka i węglowodanów niż chorzy z BMI $<25$.

\section{Wyniki badań laboratoryjnych}

Wyniki oznaczeń stężeń glukozy, białka, albuminy, prealbuminy i białka C-reaktywnego w badanych grupach przedstawiono w tabelach 1 i 2, a najważniejsze różnice istotne statystycznie między grupami w tabeli 5. Nie stwierdzono różnic istotnych statystycznie w parametrach laboratoryjnych między grupami DO-1, DO-2 i GK, za wyjątkiem niższej wartości białka C-reaktywnego w GK. Podczas półrocznej obserwacji nastąpiło istotne statystycznie obniżenie stężenia prealbuminy w grupie chorych z BMI > 25. Podział grup w zależności od BMI uwidocznił niższe stężenie prealbuminy u osób chorych w stosunku do zdrowych. Analizując różnice między grupami o różnym BMI, stwierdzono, że chorzy z BMI > 25 w stosunku do chorych z BMI < 25 charakteryzowali się większym stężeniem glukozy i białka C-reaktywnego oraz mniejszym prealbuminy. W grupie osób zdrowych zaobserwowano tylko różnice w stężeniu glukozy.

\section{DYSKUSJA I WNIOSKI}

Niedożywienie białkowo-kaloryczne jest powszechnie spotykane u pacjentów leczonych dializą otrzewnową [13, 14] i jest związane z zachorowalnością oraz śmiertelnością [15]. U pacjentów występuje zbyt niska podaż energii i białka w stosunku do zapotrzebowania. Równocześnie część składników odżywczych jest usuwana z organizmu przez nerki i/lub z płynem dializacyjnym [16]. Do płynu dializacyjnego mogą przechodzić białka i aminokwasy, a ich dobowa strata może wynosić do $10 \mathrm{~g}$ [17].

Analizowano stan odżywienia pacjentów z punktu widzenia wskaźników antropometrycznych, które porównywano z laboratoryjnymi wskaźnikami odżywienia, parametrami stanu zapalnego organizmu oraz ilością i rodzajem substancji zawartych w diecie.

Osoby chore zakwalifikowane do badania 2-krotnie wypełniały ankietę i były poddawane badaniu antropometrycznemu. Drugie badanie było wykonywane pół roku po pierwszym i miało wskazać na rolę, jaką odgrywa czas w stanie odżywienia pacjentów. Osoby stanowiące grupę kontrolną było poddawane badaniom tylko raz. Wyniki ankiet nie różniły się istotnie statystycznie między sobą. Nie stwierdzono ani zmian w stylu życia pacjentów, ani w sposobie odżywiania. W sposobie odżywiania nie zanotowano też zmian związanych z porami roku, a więc sezonowością występowania niektórych produktów spożywczych.

Grupa kontrolna i badana nie różniły się pod względem płci i wieku, jakkolwiek osoby grupy zdrowej były młodsze niż osoby chore. Brak różnic, podobnie jak w wielu innych parametrach, może wynikać z wartości odchylenia standardowego.

Osoby biorące udział w eksperymencie przez tydzień notowały wszystkie spożywane pokarmy. Zapisy oparte o „Album fotografii produktów i potraw” [12] zostały poddane analizie statystycznej, a jej wyniki posłużyły do oceny sposobu żywienia. Jeden z ważniejszych wskaźników, podaż energii, wynosił tylko ok. $60 \%$ zalecanej normy. Ponieważ podobne wyniki otrzymano w grupie osób zdrowych, można przyjąć, że niskie wartości wynikają z błędów metodologicznych, a nie z niedoborów kalorycznych występujących u pacjentów. Podobne wyniki, ale otrzymane z analizy ankiet 24-godzinnych, a nie tygodniowych, otrzymali Klahr i wsp. [18]. Rozkład pobieranej energii (z białek, tłuszczów i węglowodanów) grupy D0 w niewielkim stopniu odbiegał od normy. Pacjenci, zgodnie z zaleceniami, pobierali mniej energii z białek, a więcej z węglowodanów. Przeciwne wyniki otrzymali Klahr i wsp. [18], u których badane osoby czerpały energię głównie z tłuszczu. Jakkolwiek dieta bogata w białko zwiększa wytwarzanie toksyn 
mocznicowych [19, 20], to jego niedobory prowadzą do zwiększonego katabolizmu będącego wynikiem zarówno dializoterapii, jak i chorób pacjentów (co jest przyczyną przewlekłej choroby nerek i innych chorób temu towarzyszących) [20, 21]. Nie potwierdzono jednoznacznych korzyści wynikających ze stosowanie diety ograniczającej dowóz białek [22], natomiast niższe spożycie białek skutkuje obniżeniem stężenia albuminy, któremu towarzyszy zwiększona śmiertelność [21].

Energia pochodząca z lipidów była we wszystkich grupach nieco mniejsza niż w przyjętych normach. Spożycie błonnika w grupie DO było zdecydowanie mniejsze niż zalecane przez normy. Spowodowane było to zapewne ograniczeniami w spożywaniu warzyw i owoców, które są źródłem potasu oraz fosforu.

Jednym z ważniejszym parametrów określających stan odżywienia jest BMI. Optymalna masa ciała osób dializowanych otrzewnowo nie jest jednoznacznie ustalona. Uważa się, że nadwaga lub lekka otyłość mogą wydłużyć przeżycie pacjentów $[23,24]$. Prawidłowemu lub podwyższonemu BMI może jednak towarzyszyć niedożywienie [25]. Stwierdzono także, że otyłość ma wpływ na postęp choroby nerek oraz wzrost ryzyka wystąpienia nadciśnienia tętniczego [26, 27, 28].

Jednym z prostszych, ale nieczęsto stosowanych sposobów oceny stopnia odżywienia jest pomiar MAC oraz grubości fałdu skórnego nad mięśniem trójgłowym [29, 30]. Stosovic i wsp. [31] w badaniach przeprowadzonych na 242 osobach poddawanych hemodializie stwierdzili, że obwód środkowej części ramienia, wyliczona zawartość tłuszczu i grubość fałdu skórnego nad mięśniem trójgłowym są niezależnymi czynnikami umieralności. Autorzy nie wykazali przydatności współczynnika BMI do określania ryzyka śmiertelności [31]. Pomiędzy grupami DO a GK, uwzględniając podział na płeć, w zasadzie nie znaleziono różnic w badanych parametrach antropometrycznych. Niekorzystnym zjawiskiem był brak różnic między kobietami i mężczyznami w grupie osób chorych w obwodzie środkowej części ramienia. Badania antropometryczne osób dializowanych mogą jednak być obarczone dużym błędem wynikającym z przewodnienia. Brak jest także wystarczającej ilości pomiarów, by można było opracować wartości referencyjne dla tej grupy. Wysokie wartości BMI kojarzone są z wysoką zawartością tkanki tłuszczowej w organizmie, a niskie BMI z niską jej zawartością. Nie dotyczy to m.in. pacjentów dializowanych, u których często przewodnienie maskuje niską zawartość tkanki tłuszczowej. Zjawisko to zaobserwowano u osób chorych o wartościach BMI < 25. Stwierdzono u nich mniejszy niż w GK obwód środkowej części ramienia przy jednoczesnym braku różnic w wartościach BMI.

Stany zapalne często występują u pacjentów poddawanych hemodializie i dializie otrzewnowej [32]. Jednym ze wskaźników zapaleń jest białko ostrej fazy - CRP [33]. Stany zapalne związane są z ryzykiem chorób sercowo-naczyniowych i wzrostem śmiertelności pacjentów hemodializowanych [34], a podwyższone stężenia CRP są silnym predyktorem wszystkich przyczyn sercowo-naczyniowych śmiertelności u pacjentów zarówno poddawanych hemodializie, jak i dializie otrzewnowej $[35,36,37]$. Coraz więcej uwagi zwraca się na powiązanie stanu odżywienia ze stanem zapalnym. Kalantar-Zadeh i Kopple stwierdzili, że zapalenie jest ogniwem łączącym niedożywienie białkowo-kaloryczne ze złym stanem klinicznym pacjentów poddawanych dializie otrzewnowej [23].

Ponadto, zarówno niedożywienie białkowo-kaloryczne, jak i zapalenie są związane ze wzrostem zachorowalności i śmiertelności, w tym z ryzykiem zgonu. Stwierdzono, że stężenie białka C-reaktywnego istotnie przewiduje przeżywalność chorych. Analiza zależności między stężeniami CRP oraz prealbuminy, jako zarówno markera stanu odżywienia, jak i negatywnego wskaźnika ostrej fazy białka biorącego udział w reakcji, ukazała, że stan zapalny pacjenta powinien być uwzględniany przy ocenie stanu odżywiania [38].

W badaniach opisywanych w niniejszej pracy zaobserwowano znacznie podwyższone stężenie białka C-reaktywnego w obu grupach pacjentów. Stężenie białka C-reaktywnego w grupach DO-1 i D0-2 było wyższe od stężenia w GK. W czasie półrocznej obserwacji jego średnia wartość wzrosła 4-krotnie, mimo że nie stwierdzono silnego, jawnego procesu zapalnego u pacjentów.

Czynnikiem uważanym za jeden z ważniejszych w ocenie stanu odżywienia jest albumina. U chorych niedożywionych stwierdza się jej obniżone stężenie. Na jej stężenie ma także wpływ wiele innych czynników, w tym obecne stany zapalne czy choroby wątroby. Średnie stężenie albuminy w badanych grupach było podobne.

Oprócz albuminy równie czułym wskaźnikiem stanu odżywienia jest prealbumina [39, 40]. Nie potwierdziły tego badania własne podczas analizy bez podziału grup ze względu na wartość BMI, gdyż zarówno stężenie białka, albuminy, jak i prealbuminy były porównywalne w badanych grupach. Także analiza przeprowadzona na 250 osobach [41] wykazała, że otrzewnowy klirens białka i albuminy nie mają wpływu na przeżywalność pacjentów dializowanych.

U osób zdrowych nie stwierdzono znaczących różnic w oznaczanych parametrach biochemicznych w zależności od wartości BMI. Analogiczna zależność występuje w grupie DO-1. W tej grupie, zgodnie z oczekiwaniami, pacjenci z nadwagą i otyli mają wyższe niż szczupli wartości białka C-reaktywnego; pobierają więcej energii z białka. Niepokojące wyniki otrzymano w grupie pacjentów z nadwagą i otyłością. Pacjenci z BMI > 25 mają niższe stężenie prealbuminy, a wyższe glukozy i białka C-reaktywnego w surowicy krwi. Jednocześnie wartość kaloryczna posiłków, spożycie białka i tłuszczu jest niższe w stosunku do osób zdrowych z BMI > 25 oraz osób chorych z BMI < 25. Analiza przeprowadzona przez Kiran i wsp. [10] na prawie 300 osobach wykazała, że związek pomiędzy wartościami BMI a śmiertelnością ma kształt litery U, z wyższą śmiertelnością u pacjentów z niedowagą i nadwagą. Zhou i wsp. [11] przedstawili wyniki, z których wynika, że pacjenci, u których w chwili rozpoczęcia dializ było prawidłowe BMI, mieli znaczną przewagę przeżycia w badaniu własnym. Mechanizmy te mogą być związane z obniżeniem ryzyka chorób sercowo-naczyniowych oraz rzadziej występującego przewlekłego zapalenia otrzewnej. Chan i wsp. [42] na podstawie 10-letniej obserwacji stwierdzili, że nadwaga oraz otyłość 
nie wykazały żadnego pozytywnego wpływu na przeżycie. Zarówno niedożywienie, jak i nadwaga (lub otyłość) wiązały się z 3-krotnym wzrostem ryzyka śmierci w porównaniu z prawidłowo odżywionymi pacjentami z BMI $<25$.

Stan odżywienia wszystkich chorych poddawanych dializie otrzewnowej był nieprawidłowy, czego nie odzwierciedlał BMI. U osób z nadwagą i otyłych stwierdzono narastające w czasie zmiany sugerujące wystąpienie niedożywienia białkowo-kalorycznego. Pacjenci, szczególnie z otyłością i nadwagą, powinni być poddawani edukacji w zakresie żywienia. Stosowanie prawidłowej diety może wspomóc leczenie, wpływając na stan zdrowia i poprawę jakości życia.

\section{PIŚMIENNICTWO}

1. Ahime R.S., Flier J.S.: Adipose tissue as an endocrine organ. Trends Endocrinol Metab. 2000, 11 (8), 327-332.

2. NKF KDOQI, National Kidney Foundation Kidney Disease Outcomes Quality Initiative. www.kidney.org. (5.05.2010)

3. Churchill D.N., Taylor D.W., Keshaviah P.R.: Adequacy of dialysis and nutrition in continuous peritoneal dialysis, association with clinical outcomes. J Am Soc Nephrol. 1996, 7 (2), 198-207.

4. Ateş K., Oztemel A., Nergizoğlu G., Ertürk S., Keven K., Akar H. et al.: Peritoneal protein losses do not have a significant impact on nutritional status in CAPD patients. Perit Dial Int. 2001, 21 (5), 519-522.

5. Lindholm B., Alvestrand A., Fürst P., Bergström J.: Plasma and muscle free amino acids during continuous ambulatory peritoneal dialysis. Kidney Int. 1989, 35 (5), 1219-1226.

6. Lin W.T., Tsai C.C., Chen C.Y., Lee W.J., Su C.C., Wu Y.J.: Proteomic analysis of peritoneal dialysate fluid in patients with dialysis-related peritonitis. Ren Fail. 2008, 30 (8), 772-777.

7. Raaijmakers R., Pluk W., Schröder C.H., Gloerich J., Cornelissen E.A., Wessels H.J. et al: Proteomic profiling and identification in peritoneal fluid of children treated by peritoneal dialysis. Nephrol Dial Transplant. 2008, 23 (7), 2402-2405

8. Pliakogiannis T., Trpeski L., Taskapan H., Shah H., Ahmad M., Fenton S. et al.: Reverse epidemiology in peritoneal dialysis patients, the Canadian experience and review of the literature. Int Urol Nephrol. 2007, 39 (1), 281-288

9. Snyder J.J., Foley R.N., Gilbertson D.T., Vonesh E.F., Collins A.J.: Body size and outcomes on peritoneal dialysis in the United States. Kidney Int. 2003, 64 (5), 1838-1844.

10. Kiran V.R., Zhu T.Y., Yip T., Lui S.L., Lo W.K.: Body mass index and mortality risk in Asian peritoneal dialysis patients in Hong Kong-impact of diabetes and cardiovascular disease status. Perit Dial Int. 2014, 34 (4), 390-398.

11. Zhou H., Cui L., Zhu G., Jiang Y., Gao X., Zou Y. et al.: Survival advantage of normal weight in peritoneal dialysis patients. Ren Fail. 2011, 33 (10), 964-968.

12. Szponar L., Wolnicka K., Rychlik E.: Album fotografii produktów i potraw. IŻŻ, Warszawa 2000

13. Young G.A., Kopple J.D., Lindholm B., Vonesh E.F., De Vecchi A., Scalamogna A. et al: Nutritional assessment of continuous ambulatory peritoneal dialysis patients, an international study. Am J Kidney Dis. 1991, 17 (4), 462-471.

14. Martín-del-Campo F., Batis-Ruvalcaba C., González-Espinoza L., Rojas-Campos E., Angel J.R., Ruiz N. et al.: Dietary micronutrient intake in peritoneal dialysis patients: relationship with nutrition and inflammation status. Perit Dial Int. 2012, 32 (2), 183-191.

15. de Mutsert R., Grootendorst D.C., Axelsson J., Boeschoten E.W., Krediet R.T., Dekker F.W.: Excess mortality due to interaction between protein-energy wasting, inflammation and cardiovascular disease in chronic dialysis patients. Nephrol Dial Transplant. 2008, 23 (9), 2957-2964.

16. Kalantar-Zadeh K., Kopple J.D.: Trace elements and vitamins in maintenance dialysis patients. Adv Ren Replace Ther. 2003, 10 (3), 170-182.

17. Daugirdas J., Blake P., Ing T.: Podręcznik dializoterapii. Czelej, Lublin 2008.

18. Klahr S., Levey A.S., Beck G.J., Caggiula A.W., Hunsicker L., Kusek J.W. et al.: The effects of dietary protein restriction and blood-pressure control on the progression of chronic renal disease. Modification of Diet in Renal Disease Study Group. N Engl J Med. 1994, 330 (13), 877-884.

19. Mitch W.E.: Dietary therapy in uremia: the impact on nutrition and progressive renal failure. Kidney Int. 2000, 57, Suppl. 75, 38.

20. Locatelli F., Fouque D., Heimburget O., Drüeke T.B., Cannata-Andía J.B., Hörl W.H. et al.: Nutritional status in dialysis patients, European consensus. Nephrol Dial Transplant. 2002, 17 (4), 563-572.

21. Mak R.K., Cheung W.: Energy homeostasis and cachexia in chronic kidney disease. Pediatr Nephrol. 2006, 21 (12), 1807-1814.

22. Levey A.S., Adler S., Caggiula A.W., England B.K., Greene T., Hunsicker L.G. et al.: Effects of dietary protein restriction on the progression of advanced renal disease in the Modification of Diet in Renal Disease Study. Am J Kidney Dis. 1996, 27 (5), 652-663.

23. Kalantar-Zadeh K., Kopple J.D.: Relative contributions of nutrition and inflammation to clinical outcome in dialysis patients. Am J Kidney Dis. 2001, 38 (6), 1343-1350.

24. de Luis D., Bustamante J.: Nutritional aspects in renal failure. Nefrologia. 2008, 28 (3), 333-342.

25. Postorino M., Marino C., Tripepi G., Zoccali C.: Abdominal obesity and all-cause and cardiovascular mortality in end-stage renal disease. J Am Coll Cardiol. 2009, 53 (15), 1265-1272.

26. Praga M., Morales E.: Obesity, proteinuria and progression of renal failure. Curr Opin Nephrol Hypertens. 2006, 15 (5), 481-486.

27. Drechsler C., de Mutsert R., Grootendorst D.C., Boeschoten E.W., Krediet R.T., le Cessie S. et al.: Association of body mass index with decline in residual kidney function after initiation of dialysis. Am J Kidney Dis. 2009, 53 (6), 1014-1023.

28. Johnson D.W.: Dietary protein restriction as a treatment for slowing chronic kidney disease progression, the case against. Nephrology (Carlton). 2006, $11(1), 58-62$.

29. Kamimura M.A., Avesani C.M., Cendoroglo M., Canziani M.E., Draibe S.A., Cuppari L.: Comparison of skinfold thicknesses and bioelectrical impedance analysis with dual-energy X-ray absorptiometry for the assessment of body fat in patients on long-term haemodialysis therapy. Nephrol Dial Transplant. 2003, 18 (1), 101-105.

30. Schoenfeld P., Henry R., Laird N., Roxe D.M.: Assessment of nutritional status of the National Cooperative Dialysis Study population. Kidney Int. 1983, 23, S80-S85.

31. Stosovic M., Stanojevic M., Simic-Ogrizovic S., Jovanovic D., Djukanovic L.: The predictive value of anthropometric parameters on mortality in haemodialysis patients. Nephrol Dial Transplant. 2011, 26 (4), 1367-1374.

32. Stenvinkel P., Alvestrand A.: Inflammation in end-stage renal disease: sources, consequences, and therapy. Semin Dial. 2002, 15 (5), 329-337.

33. Lacson E. Jr, Levin N.W.: C-reactive protein and end-stage renal disease. Semin Dial. 2004, 17 (6), 438-448.

34. Zimmermann J., Herrlinger S., Pruy A., Metzger T., Wanner C.: Inflammation enhances cardiovascular risk and mortality in hemodialysis patients. Kidney Int. 1999, 55 (2), 648-658.

35. Owen W.F., Lowrie E.G.: C-reactive protein as an outcome predictor for maintenance hemodialysis patients. Kidney Int. 1998, 54 (2), 627-636.

36. Yeun J.Y., Levine R.A., Mantadilok V., Kaysen G.A.: C-reactive protein predicts all-cause and cardiovascular mortality in hemodialysis patients. Am J Kidney Dis. 2000, 35 (3), 469-476.

37. Avram M.M., Fein P.A., Paluch M.M., Schloth T., Chattopadhyay J.: Association between $\mathrm{C}$-reactive protein and clinical outcomes in peritoneal dialysis patients. Adv Perit Dial. 2005, 21, 154-158.

38. Wang A.Y., Woo J., Lam C.W., Wang M., Sea M.M., Lui S.F. et al.: Is a single time point $C$-reactive protein predictive of outcome in peritoneal dialysis patients? J Am Soc Nephrol. 2003, 14 (7), 1871-1879.

39. Hakim R.M., Levin N.: Malnutrition in hemodialysis patients. Am J Kidney Dis. 1993, 21 (2), 125-137.

40. Mittman N., Avram M.M., Oo K.K., Chattopadhyay J.: Serum prealbumin predicts survival in hemodialysis and peritoneal dialysis, 10 years of prospective observation. Am J Kidney Dis. 2001, 38, 1358-1364.

41. Balafa O., Halbesma N., Struijk D.G., Dekker F.W., Krediet R.T.: Peritoneal albumin and protein losses do not predict outcome in peritoneal dialysis patients. Clin J Am Soc Nephrol. 2011, 6 (3), 561-566.

42. Chan M., Kelly J., Batterham M., Tapsell L.: Malnutrition (subjective global assessment) scores and serum albumin levels, but not body mass index values, at initiation of dialysis are independent predictors of mortality, a 10-year clinical cohort study. J Ren Nutr. 2012, 22 (6), 547-557. 